\title{
Assessment of Denitrification Gaseous End-Products in the Soil Profile under Two Water Table Management Practices Using Repeated Measures Analysis
}

\author{
Abdirashid A. Elmi,* Tess Astatkie, Chandra Madramootoo, Robert Gordon, and David Burton
}

\begin{abstract}
The denitrification process and nitrous oxide $\left(\mathrm{N}_{2} \mathrm{O}\right)$ production in the soil profile are poorly documented because most research into denitrification has concentrated on the upper soil layer $(0-0.15 \mathrm{~m})$. This study, undertaken during the 1999 and 2000 growing seasons, was designed to examine the effects of water table management (WTM), nitrogen $(\mathrm{N})$ application rate, and depth $(0.15,0.30$, and $0.45 \mathrm{~m})$ on soil denitrification end-products $\left(\mathrm{N}_{2} \mathrm{O}\right.$ and $\left.\mathrm{N}_{2}\right)$ from a corn (Zea mays $\left.\mathrm{L}_{\text {. }}\right)$ field. Water table management treatments were free drainage (FD) with open drains and subirrigation (SI) with a target water table depth of $0.6 \mathrm{~m}$. Fertility treatments (ammonium nitrate) were $120 \mathrm{~kg} \mathrm{~N} \mathrm{ha}^{-1}$ (N120) and $200 \mathrm{~kg} \mathrm{~N} \mathrm{ha}^{-1}$ (N200). During both growing seasons greater denitrification rates were measured in SI than in FD, particularly in the surface soil $(0-0.15 \mathrm{~m})$ and at the intermediate $(0.15-0.30 \mathrm{~m})$ soil depths under N200 treatment. Greater denitrification rates under the SI treatment, however, were not accompanied with greater $\mathrm{N}_{2} \mathrm{O}$ production. The decrease in $\mathrm{N}_{2} \mathrm{O}$ production under SI was probably caused by a more complete reduction of $\mathrm{N}_{2} \mathrm{O}$ to $\mathrm{N}_{2}$, which resulted in lower $\mathrm{N}_{2} \mathrm{O}$ to $\left(\mathrm{N}_{2} \mathrm{O}+\mathrm{N}_{2}\right)$ ratios. Denitrification rate, $\mathrm{N}_{2} \mathrm{O}$ production and $\mathrm{N}_{2} \mathrm{O}$ to $\left(\mathrm{N}_{2} \mathrm{O}+\mathrm{N}_{2}\right)$ ratios were only minimally affected by $\mathrm{N}$ treatments, irrespective of sampling date and soil depth. Overall, half of the denitrification occurred at the 0.15- to 0.30- and 0.30- to 0.45-m soil layers, and under SI, regardless of fertility treatment level. Consequently, sampling of the 0- to $0.15-\mathrm{m}$ soil layer alone may not give an accurate estimation of denitrification losses under SI practice.
\end{abstract}

$\mathrm{W}$ ATER TABLE MANAgement has been proposed as a beneficial management practice for bioremediation of nitrate $\mathrm{N}\left(\mathrm{NO}_{3}^{-}-\mathrm{N}\right)$ contaminated soils by enhancing denitrification (Elmi et al., 2002a; Jacinthe et al., 2000; Kliewer and Gilliam, 1995). Denitrification is the major biological process by which $\mathrm{NO}_{3}^{-}-\mathrm{N}$ is reduced to $\mathrm{N}_{2}$, with $\mathrm{N}_{2} \mathrm{O}$ being an intermediary product. Nitrous oxide emissions have been a topic of increasing concern because $\mathrm{N}_{2} \mathrm{O}$ contributes to the atmospheric greenhouse gas concentration and has a well-documented role in stratospheric ozone depletion (Duxbury et al., 1982).

Although most previous studies have concentrated on the top $0.15 \mathrm{~m}$ of the soil surface, some researchers have reported increased denitrification in subsoils if water-soluble carbon (WSC) is not limited (Ryan et al., 1998; Jarvis and Hatch, 1994). McCarty and Bremner (1992) measured denitrification in subsurface soils (up to a 2-m depth) and reported negligible denitrification in response to added $\mathrm{NO}_{3}^{-}-\mathrm{N}$ alone, but the addition

A.A. Elmi, T. Astatkie, R. Gordon, and D. Burton, Department of Engineering, Nova Scotia Agricultural College, P.O. Box 550, Truro, NS, Canada B2N 5E3. C. Madramootoo, Brace Center for Water Resources Management, Macdonald Campus of McGill University, 21111 Lakeshore Rd. Ste-Anne-de-Bellevue, Quebec, Canada H9X 3V9. Received 27 Aug. 2004. *Corresponding author (abdirashid.elmi@elf. mcgill.ca)

Published in J. Environ. Qual. 34:446-454 (2005).

(c) ASA, CSSA, SSSA

677 S. Segoe Rd., Madison, WI 53711 USA of both $\mathrm{NO}_{3}^{-}-\mathrm{N}$ and glucose stimulated denitrification activity. They concluded that denitrification processes in subsurface soils are primarily limited by the availability of WSC. Water-soluble C provides microorganisms with an energy source and thus may play a dominant role in defining the capacity of agroecosystems to act as $\mathrm{NO}_{3}^{-}-\mathrm{N}$ sinks.

Denitrification processes occurring in the subsoil environment can be an important mechanism to help mitigate $\mathrm{NO}_{3}^{-}-\mathrm{N}$ contamination of ground and surface waters. A series of studies conducted previously (Elmi et al., 2002a) and concurrent with the study reported here (Elmi et al., 2004) at the same field site reported that SI reduced $\mathrm{NO}_{3}^{-}-\mathrm{N}$ accumulation in the soil profile and, consequently, improved drainage water quality. Whether $\mathrm{NO}_{3}^{-}-\mathrm{N}$ removal by denitrification is beneficial to the wider environment, however, depends on whether the dominant end-product of $\mathrm{NO}_{3}^{-}-\mathrm{N}$ reduction is $\mathrm{N}_{2} \mathrm{O}$ or $\mathrm{N}_{2}$. We hypothesize that $\mathrm{N}_{2} \mathrm{O}$ produced at deeper soil depths will take longer to diffuse, providing an opportunity for further reduction of $\mathrm{N}_{2} \mathrm{O}$ to $\mathrm{N}_{2}$ before escaping to the atmosphere. Despite this potential for denitrification in subsurface soil to help mitigate $\mathrm{NO}_{3}^{-}-\mathrm{N}$ pollution without a concomitant increase in $\mathrm{N}_{2} \mathrm{O}$ emissions, the interactive effects of WTM and N fertilization practices on subsurface $\mathrm{N}_{2} \mathrm{O}$ production have not been investigated under field conditions. Examination of subsoil denitrification will improve our knowledge gap in $\mathrm{N}$ transformations and future environmental risk assessment associated with the emissions of $\mathrm{N}_{2} \mathrm{O}$ from agroecosystems. The objectives of this study were, therefore, to examine denitrification rates, $\mathrm{N}_{2} \mathrm{O}$ production, and $\mathrm{N}_{2} \mathrm{O}$ to $\left(\mathrm{N}_{2} \mathrm{O}+\mathrm{N}_{2}\right)$ ratio in the soil profile as influenced by WTM, N fertilization rate, and soil depth from a corn field during two cropping seasons.

\section{MATERIALS AND METHODS}

\section{Field Management and Experimental Design}

Experimental layout, treatment arrangements, and field operations are described in Elmi et al. (2002b). Briefly, we conducted this study on a corn field (4.2 ha) located at St-Emmanuel, Quebec, Canada. The soil is classified as a Soulanges fine sandy loam (fine silty; mixed, nonacid, frigid Humaquept, Gleysol, according to the FAO classification system). The fine sandy loam soil $(0-0.25 \mathrm{~m})$ was underlain by layers of sandy clay loam $(0.25-0.55 \mathrm{~m})$ and clay $(0.55-1.0 \mathrm{~m})$, and the clay layer impeded the natural drainage. The soil contained $50 \mathrm{~g}$ $\mathrm{C} \mathrm{kg}^{-1}$ soil (fresh wt.) in the 0 - to 0.25 -m layer, $15 \mathrm{~g} \mathrm{C} \mathrm{kg}^{-1}$ soil (fresh wt.) in the 0.25 - to $0.55-\mathrm{m}$ layer, and a negligible amount of $\mathrm{C}$ below $0.55 \mathrm{~m}$. The $\mathrm{pH}(0.45-\mathrm{m}$ depth) was near

Abbreviations: FD, free drainage; N120, $120 \mathrm{~kg} \mathrm{~N} \mathrm{ha}^{-1}$; N200, $200 \mathrm{~kg}$ $\mathrm{N} \mathrm{ha}^{-1}$; SI, subirrigation; WSC, water-soluble carbon; WTM, water table management. 
neutral (6.8). Primary tillage after harvest consisted of moldboard plowing to a depth of 0.15 to $0.20 \mathrm{~m}$. Secondary tillage consisted of disking before planting.

There were two WTM treatments: FD with open drains and SI with a target water table depth of $0.6 \mathrm{~m}$, factorially combined with two $\mathrm{N}$ fertility rates: $120 \mathrm{~kg} \mathrm{~N}^{-1}$ (N120) and $200 \mathrm{~kg} \mathrm{~N} \mathrm{ha}^{-1}$ (N200). Diammonium phosphate (18-46-0) was banded at planting to provide approximately $24 \mathrm{~kg} \mathrm{~N}^{-1}$ and $130 \mathrm{~kg} \mathrm{P}_{2} \mathrm{O}_{5} \mathrm{ha}^{-1}$. In each year, one month after seeding, 97 and $178 \mathrm{~kg} \mathrm{~N} \mathrm{ha}^{-1}$ were broadcast as ammonium nitrate (34-0-0) for the N120 and N200 treatments, respectively, to reach desired $\mathrm{N}$ levels. These second applications occurred on 10 June 1999 and 20 June 2000. The four treatment combinations of water table and fertility rate were randomized in $15-\times 75-\mathrm{m}$ plots. There were three blocks $(120 \mathrm{~m}$ wide and $75 \mathrm{~m}$ long, including four buffer plots) separated by a 30-m-wide strip of undrained land. In the middle of each plot, 75-mm-diameter subsurface drain pipes were laid (1.0-m depth and $30-\mathrm{m}$ spacing) on a $0.3 \%$ slope. The SI treatment was imposed two weeks after planting and maintained until crop maturity in late September. Subirrigation was switched to FD on 17 Sept. 1999 and 15 Sept. 2000.

Three observation wells (pipes wrapped with geotextile [Zodiac, London, ON, Canada]) were installed diagonally across each of the treatment and buffer plots to a depth of approximately $1.5 \mathrm{~m}$. A graduated rod with a sonic water sensor was used to monitor water table levels. Following heavy rainfall events, pumping was stopped manually in SI plots and excess water drained until a $0.6-\mathrm{m}$ water table depth was achieved. Water table levels under both WTM treatments fluctuated throughout growing seasons, responding to the amount of rainfall and intensity (Elmi et al., 2004).

Rainfall and air temperature data were obtained from an Environment Canada weather station $500 \mathrm{~m}$ from the site. Based on a 30-yr average, the climate at the experimental site has a monthly mean temperature of $15^{\circ} \mathrm{C}$ and a mean precipitation of $522.2 \mathrm{~mm}$ during the growing season (MayOctober). Total seasonal rainfall in 1999 was $13 \%$ higher than normal with almost half (47\%) of the rainfall occurring in September and October. In 2000 it was about $12 \%$ higher than normal, with May being the wettest month (twofold the norm) and October the driest month (less than half the norm) of this growing season. Mean monthly temperatures at the site during the growing season (May-October) were $1.6^{\circ} \mathrm{C}$ higher in 1999 than the $30 \mathrm{yr}$ average, while 2000 followed the long-term average.

\section{Denitrification and Nitrous Oxide Measurements}

Denitrification was measured using the intact core incubation method with acetylene $\left(\mathrm{C}_{2} \mathrm{H}_{2}\right)$ inhibition (Ryden et al., 1987). Three incremental depths $(0-0.15,0.15-0.30,0.30-0.45 \mathrm{~m})$ were sampled simultaneously in pairs. Due to the heavy labor commitment, time constraints related to sampling and incubating cores, and analytical costs, it was only feasible to collect one pair of samples from each treatment plot for each sampling date. There were six (9 June, 7 July, 28 July, 26 August, 18 September, and 20 October) and eight (28 May, 22 June, 6 July, 19 July, 3 August, 17 August, 19 September, 20 October) sampling dates for 1999 and 2000, respectively.

On each sampling date, aluminum cylinders $(50 \mathrm{~mm}$ in diameter $\times 150 \mathrm{~mm}$ long) were used to collect soil cores of three depth increments $(0-0.15,0.15-0.30,0.30-0.45 \mathrm{~m})$. Samples were collected from randomly selected locations in the non-wheel-tracked middle rows of each plot and they were never taken from the same location (hole) more than once within the growing season. Samples were placed in $2-\mathrm{L}$ plastic jars fitted with rubber stoppers for gas sampling. One hundred milliliters of the headspace in the jars was removed from one sample of each pair and replaced with $100 \mathrm{~mL}$ of $\mathrm{C}_{2} \mathrm{H}_{2}$ to give a $5 \%(\mathrm{v} / \mathrm{v})$ concentration. The second sample was not treated with $\mathrm{C}_{2} \mathrm{H}_{2}$. All samples were buried at the 0- to 0.15-m depth in an attempt to mimic field conditions for a 24-h incubation.

Headspace gas was thoroughly mixed by inserting a syringe and pumping several times before gas sampling. About $4 \mathrm{~mL}$ of headspace gas was removed from the jars and injected into a gas chromatograph (GC) (Model 5870 Series II; HewlettPackard, Palo Alto, CA) equipped with a ${ }^{63} \mathrm{Ni}$ electron capture detector (ECD) using Ar and $\mathrm{CH}_{4}$ (95:5) as a carrier gas, with oven and detector temperatures adjusted to 70 and $400^{\circ} \mathrm{C}$, respectively.

The consequence of $\mathrm{C}_{2} \mathrm{H}_{2}$ treatment is the inhibition of the $\mathrm{N}_{2} \mathrm{O}$-reductase enzyme, allowing $\mathrm{N}_{2} \mathrm{O}$ to accumulate as a measure of total denitrification $\left(\mathrm{N}_{2} \mathrm{O}+\mathrm{N}_{2}\right)$ (Ryden et al., 1987). The production of $\mathrm{N}_{2} \mathrm{O}$ by denitrification was estimated by the amount of $\mathrm{N}_{2} \mathrm{O}$ evolved from soil cores without $\mathrm{C}_{2} \mathrm{H}_{2}$, whereas total denitrification $\left(\mathrm{N}_{2} \mathrm{O}+\mathrm{N}_{2}\right)$ was estimated from the amounts of $\mathrm{N}_{2} \mathrm{O}$ produced from $\mathrm{C}_{2} \mathrm{H}_{2}$-amended soil cores. In the remainder of this paper, the quantities of $\mathrm{N}_{2} \mathrm{O}$ produced with and without $\mathrm{C}_{2} \mathrm{H}_{2}$ addition are referred to as $\mathrm{N}_{2} \mathrm{O}$ and $\mathrm{N}_{2} \mathrm{O}+\mathrm{N}_{2}$, respectively. The mole fraction of $\mathrm{N}_{2} \mathrm{O}$, defined as $\mathrm{N}_{2} \mathrm{O}$ to $\left(\mathrm{N}_{2} \mathrm{O}+\mathrm{N}_{2}\right)$ ratio, was estimated as the ratio of $\mathrm{N}_{2} \mathrm{O}$ measured without $\mathrm{C}_{2} \mathrm{H}_{2}$ to that produced with $\mathrm{C}_{2} \mathrm{H}_{2}$ (Aulakh et al., 1984).

\section{Water-Soluble Carbon}

Three soil samples were collected from each plot using an auger before planting and after harvest. Samples were combined to make composite samples. To extract WSC, $10 \mathrm{~g}$ of field moist subsample was shaken in $100 \mathrm{~mL}$ of deionized distilled water for $1 \mathrm{~h}$, centrifuged at $10000 \mathrm{rpm}$ for $10 \mathrm{~min}$, and then filtered through \#5 paper (Whatman, Maidstone, UK). Samples were analyzed using a Model TOC-5000A analyzer (Shimadzu, Kyoto, Japan).

\section{Statistical Methods: Repeated Measures Analysis}

Separate repeated measures analysis was completed for each of 1999 and 2000 because the levels of one of the factors of interest, sampling date, were different in the two years. For each year, the location in the field was considered as a random blocking factor, and the other four factors: fertilizer $(\mathrm{N})$, WTM, depth, and sampling date (date) were considered fixed factors. Although the layout of the experiment does not allow randomization of the three depths, the levels of N and WTM were completely randomized. The levels of date cannot be randomized, as the response measurements [denitrification end products and their ratios; $\mathrm{N}_{2} \mathrm{O}, \mathrm{N}_{2} \mathrm{O}+\mathrm{N}_{2}$, and $\mathrm{N}_{2} \mathrm{O}$ to $\left(\mathrm{N}_{2} \mathrm{O}+\mathrm{N}_{2}\right)$ ratio] were collected repeatedly over six and eight sampling dates in 1999 and 2000, respectively. Because the values of the response variables follow a certain pattern (i.e., it is not random), the independence assumption on the error terms required for the analysis of variance (ANOVA) of a factorial model (Montgomery, 2001) was unlikely to be met.

Generally, with repeated measurements such as this one, two measurements taken at adjacent times are typically more highly correlated than two measurements taken several time points apart (Littell et al., 1996). Moreover, the variability in the response measurements from different dates tended to change with the magnitude of the measurements, which may lead to the violation of the constant variance (uniform sources of experimental error) assumption. Therefore, the appropriate assumption on the error terms for this experiment was normal 
Table 1. The $p$ values of all main and interaction fixed effects estimated using the restricted maximum likelihood (REML) method with compound symmetry $(\mathrm{CS})$ covariance structure on the log-transformed values.

\begin{tabular}{|c|c|c|c|c|c|c|}
\hline \multirow[b]{2}{*}{ Source of variation } & \multicolumn{2}{|c|}{$\mathbf{N}_{2} \mathbf{O}+\mathbf{N}_{2}$} & \multicolumn{2}{|c|}{$\mathbf{N}_{2} \mathbf{O}$} & \multicolumn{2}{|c|}{$\mathbf{N}_{2} \mathrm{O}$ to $\left(\mathbf{N}_{2} \mathbf{O}+\mathbf{N}_{2}\right)$ ratio } \\
\hline & 1999 & 2000 & 1999 & 2000 & 1999 & 2000 \\
\hline $\mathbf{N}$ & 0.079 & 0.233 & 0.939 & 0.035 & 0.311 & 0.254 \\
\hline $\mathbf{W T M} \dagger$ & 0.001 & 0.001 & 0.001 & 0.649 & 0.001 & 0.001 \\
\hline $\mathbf{N} \times \mathbf{W T M}$ & 0.004 & 0.700 & 0.231 & 0.612 & 0.724 & 0.406 \\
\hline Depth & 0.001 & 0.001 & 0.040 & 0.013 & 0.001 & 0.001 \\
\hline $\mathbf{N} \times$ depth & 0.159 & 0.964 & $0.043 \div$ & 0.232 & 0.349 & 0.166 \\
\hline WTM $\times$ depth & 0.593 & 0.001 & 0.843 & 0.075 & 0.239 & 0.286 \\
\hline $\mathbf{N} \times \mathbf{W T M} \times$ depth & 0.028 & 0.799 & 0.698 & 0.253 & 0.100 & 0.188 \\
\hline Date & 0.001 & 0.001 & 0.001 & 0.001 & 0.002 & 0.001 \\
\hline $\mathbf{N} \times$ date & 0.297 & 0.013 & 0.210 & 0.043 & 0.051 & 0.001 \\
\hline WTM $\times$ date & 0.001 & 0.001 & 0.001 & 0.007 & 0.004 & 0.163 \\
\hline $\mathbf{N} \times \mathbf{W T M} \times$ date & 0.001 & 0.064 & 0.230 & 0.221 & 0.425 & $\mathbf{0 . 0 3 7}$ \\
\hline Depth $\times$ date & 0.002 & 0.001 & 0.015 & 0.005 & 0.001 & 0.161 \\
\hline $\mathbf{N} \times$ depth $\times$ date & 0.899 & 0.783 & 0.578 & 0.709 & 0.636 & 0.249 \\
\hline WTM $\times$ depth $\times$ date & 0.003 & 0.725 & 0.203 & 0.782 & 0.001 & 0.602 \\
\hline $\mathbf{N} \times \mathbf{W T M} \times$ depth $\times$ date & 0.878 & 0.028 & 0.943 & 0.231 & 0.984 & 0.045 \\
\hline
\end{tabular}

$\dagger$ Water table management.

† Means comparisons of interaction effects whose $\boldsymbol{p}$ values are shown in italic type are discussed in subsequent tables.

distribution with heterogeneous (nonconstant) variance by date, and a covariance structure of $\Sigma$. The appropriate covariance structure for each response variable was determined using Akaike's Information Criterion (AIC) and Schwarz's Bayesian Criterion (BIC), which are essentially log likelihood values penalized for the number of parameters estimated (Littell et al., 1996).

We used the mixed procedure in SAS (SAS Institute, 1999), specifically written for analyzing mixed effects and repeated measures with nonconstant variance and any covariance structure models, to analyze our data. In a preliminary analysis, the normality of the error terms for all three response variables was found to be violated on the original scale, but was met with logarithmic values. Also, according to the AIC and the $\mathrm{BIC}$, the best covariance structure was determined to be compound symmetry (CS), with heterogeneous variance-covariance parameters for different sampling dates. Water-soluble $\mathrm{C}$ and $\mathrm{pH}$ were considered as covariates, but because they were not significant in any of the responses they were excluded from the model. The statistical test results are based on the log values, and with different variances for the different sampling dates, and with the CS covariance structure. As shown in Table 1, up to four factor interaction effects were significant. Therefore, means comparison results, starting with the highest order significant interaction, were completed by generating letter groupings of the least squares means. Because these significant interactions gave a large number of treatment combinations, the letter groupings were based on the TukeyKramer adjusted $p$ values to control Type I error rates (SAS Institute, 1999).

To facilitate easy reading of the results presented in Tables 2 to 7 , the least squares means were back-transformed to the original scale, and the groupings done within and across sampling dates.

\section{RESULTS AND DISCUSSION}

\section{Denitrification Rates in the Soil Profile}

A summary of repeated measures analysis results of the main and interaction effects for both years is presented in Table 1. In 1999, both WTM and N treatments interacted significantly with depth and date of sampling (Table 1), with highest denitrification rates being pro- duced on 7 July under both WTM treatments (Table 2). Within the SI treatment, plots receiving higher $\mathrm{N}$ rate $\left(200 \mathrm{~kg} \mathrm{~N} \mathrm{ha}^{-1}\right)$ produced greater denitrification rates than the lower $\mathrm{N}$ rate $\left(120 \mathrm{~kg} \mathrm{~N} \mathrm{ha}^{-1}\right)$ only on $7 \mathrm{July}$ at the 0 - to 0.15 -m depth (Table 2). In contrast, denitrification rates were not affected by $\mathrm{N}$ treatment under FD at any sampling date. Generally, our results indicate that the addition of $200 \mathrm{~kg} \mathrm{~N}^{-1}$ relative to $120 \mathrm{~kg} \mathrm{~N}^{-1}$ does not play a significant role in soil denitrification.

The lack of $\mathrm{N}$ rate effect appears contradictory to the widely reported (Ellis et al., 1998; MacKenzie et al., 1997) findings that the application rate of $\mathrm{N}$ fertilizers has a significant influence on denitrification. One plausible explanation may be that there was sufficient $\mathrm{NO}_{3}^{-}-\mathrm{N}$ in the soil even at the lowest rate of $\mathrm{N}$ application for denitrification to occur. If this is correct, an important management implication would be that manipulating $\mathrm{N}$ fertilizer rate alone may not be a sufficient strategy to control $\mathrm{N}_{2} \mathrm{O}$ emissions under certain situations. The $\mathrm{NO}_{3}^{-}-\mathrm{N}$ concentrations in the soil solution as well as in drainage effluent have been reported in Elmi et al. (2004). Briefly, $\mathrm{NO}_{3}^{-}-\mathrm{N}$ average levels were greater than $5 \mathrm{mg} \mathrm{kg}{ }^{-1}$ at a depth of 0 to $0.75 \mathrm{~m}$. The $\mathrm{NO}_{3}^{-}-\mathrm{N}$ levels were greater during the growing season (May-October) under all treatments. With soil $\mathrm{NO}_{3}^{-}-\mathrm{N}$ concentrations at that level, it is apparent that ammonium was high enough to support nitrification.

The lack of differences between the two $\mathrm{N}$ treatments may also be related to the sampling scheme. Both denitrification and $\mathrm{N}_{2} \mathrm{O}$ are strongly episodic in nature and peak values that can contribute significantly to overall production might have been missed with the kind of sampling intensity used in this study. As noted previously, the work reported is labor-intensive and more frequent sampling was not feasible. From a practical point of view, more frequent sampling would also have caused extensive damage (depressional areas) to the field, creating technical difficulties for water table management and future field operations.

With respect to sampling depth, the effect was not consistent under either WTM treatment (Table 2). Within $\mathrm{FD}$, for example, 7 July was the only sampling date 
Table 2. Mean denitrification rate (back-transformed to the original scale) of all treatment combinations of two significant three-factor $(\mathrm{N} \times$ water table management $[$ WTM] $\times$ date; WTM $\times$ depth $\times$ date $)$ interaction effects in 1999. $\dagger$

\begin{tabular}{|c|c|c|c|c|c|c|c|c|}
\hline \multirow[b]{2}{*}{ WTM } & \multirow[b]{2}{*}{$\mathbf{N}$} & \multirow[b]{2}{*}{ Depth } & \multicolumn{6}{|c|}{ Date } \\
\hline & & & 9 June & 7 July & 28 July & 26 August & 18 September & 20 October \\
\hline & $\operatorname{kg~N} \mathbf{h a}^{-1}$ & $\mathbf{m}$ & & & $-\mathrm{g}$ & $d^{-1}$ & & \\
\hline \multirow[t]{2}{*}{ SI } & 120 & & B 4.94 & A $14.40 \mathrm{~b}$ & B $6.36 \mathrm{a}$ & B 6.64 a & C $1.50 \mathrm{a}$ & C $2.05 \mathrm{a}$ \\
\hline & 200 & & В 6.53 & A 70.97 a & B 7.05 a & B 6.65 a & C 1.19 a & C 0.94 b \\
\hline \multirow[t]{2}{*}{ FD } & 120 & & B 5.27 & A 15.59 b & C 0.82 b & C 0.23 b & C 0.34 ab & C 0.65 b \\
\hline & 200 & & A 3.52 & A 5.14 b & B 0.54 b & C 0.13 b & C 0.08 b & В 0.70 b \\
\hline \multirow[t]{3}{*}{ SI } & & 0.15 & B 10.99 & A 50.50 a & B 9.05 a & B 8.96 a & BC 2.83 a & C $1.43 \mathrm{a}$ \\
\hline & & 0.30 & BC 7.53 & A 19.83 b & AB 13.10 a & AB 14.26 a & C $2.32 \mathrm{a}$ & C $2.01 \mathrm{a}$ \\
\hline & & 0.45 & B 2.22 & A 32.62 ab & B 2.53 ab & B $2.30 \mathrm{~b}$ & B 0.36 ab & B 0.93 ab \\
\hline \multirow[t]{3}{*}{ FD } & & 0.15 & В 5.02 & A 33.50 ab & C 0.82 bc & C $0.24 \mathrm{c}$ & C 0.16 b & C 0.74 b \\
\hline & & 0.30 & A 10.03 & A 9.34 bc & C 0.97 bc & C $0.18 \mathrm{c}$ & C 0.18 b & C 0.66 b \\
\hline & & 0.45 & ВC 1.59 & AB 2.29 c & C $0.36 \mathrm{c}$ & C $0.11 \mathrm{c}$ & C 0.17 b & C 0.63 b \\
\hline
\end{tabular}

$\uparrow$ Means preceded by the same uppercase letter (within rows) and means followed by the same lowercase letters (within columns) are not significantly different (Tukey-Kramer adjusted $p>0.05$ ).

$\uparrow$ SI, subirrigation; FD, free drainage.

when the denitrification rate in the two upper layers $(0-0.15$ and $0.15-0.30 \mathrm{~m})$ was significantly $(p<0.05)$ greater than the deepest $(0.45 \mathrm{~m})$ soil depth. Furthermore, depth effects diminished as sampling period progressed, with only a trace amount of denitrification measured under FD regardless of sampling depth. Under SI, however, 26 August was the only sampling date when denitrification in the two upper layers $(0-0.15$ and $0.15-0.30 \mathrm{~m})$ was significantly $(p<0.05)$ greater than in the deepest $(0.45 \mathrm{~m})$ soil layer (Table 2$)$. When comparing between SI and FD, it is evident that SI produced greater denitrification than FD in most sampling dates at the corresponding depths, but the effect was more pronounced at the surface $(0-0.15 \mathrm{~m})$ and intermediate $(0.15-0.30 \mathrm{~m})$ depths. Enhanced denitrification in the 0.15 - to 0.30 - $\mathrm{m}$ soil layer under SI indicates the existence of favorable conditions for denitrification to occur at a depth below $0.15 \mathrm{~m}$.

In 2000, there was a significant $(p<0.05)$ four-way $(\mathrm{N} \times \mathrm{WTM} \times$ depth $\times$ date $)$ interaction (Table 1), making the interpretation of the data somewhat difficult. We therefore presented the data graphically (Fig. 1) to make it easier to understand the results, with detailed statistical findings reported in Table 3. Denitrification rates under FD did not change consistently with time, regardless of $\mathrm{N}$ level and depth (Fig. 1, Table 3). For example, denitrification rates from the upper soil layers (0.15- and 0.30-m depths) under FD with $200 \mathrm{~kg} \mathrm{~N} \mathrm{ha}^{-1}$ applied were not affected by the sample date (Table 3 ). Under SI denitrification rates remained high throughout the season, reaching maximum on 3 August in all sampling depths (Fig. 1), six weeks after $\mathrm{N}$ was applied. These observations are consistent with Koops et al. (1996), who estimated that denitrification rates from the 0 - to $0.40-\mathrm{m}$ soil layer increased twofold a few weeks after $\mathrm{N}$ fertilizer application on a grassland ecosystem. Similarly, Velthof et al. (1996) reported that $\mathrm{N}_{2} \mathrm{O}$ losses from deeper layers were most significant after application of $\mathrm{N}$ fertilizer. With respect to depth effect, greater denitrification rates were measured at the uppermost $(0-0.15 \mathrm{~m})$ and intermediate $(0.15-0.30 \mathrm{~m})$ depths than at the lowest depth (Table 3). The effect, however, was more pronounced under SI combined with the higher $\left(200 \mathrm{~kg} \mathrm{~N} \mathrm{ha}^{-1}\right) \mathrm{N}$ rate $(\mathrm{SI}+\mathrm{N} 200)$ than FD receiving similar $\mathrm{N}$ rate $(200$ $\mathrm{kg} \mathrm{N} \mathrm{ha}{ }^{-1}$ ). This observation suggests that $\mathrm{N}$ effects on denitrification may be more pronounced under SI management than under FD management.

Soil moisture exerts an important control on denitrification and the proportion of gaseous end-products. Consistent with our previous report (Elmi et al., 2002b), soil water contents (water-filled pore space) were higher under SI than FD at nearly each depth and ranged between 40 to $60 \%$ under FD and 60 to $80 \%$ under SI. Filling more soil pores with water under SI would have increased volume of anaerobic zones within soil profile, creating conditions conducive to denitrification processes. We calculated that under the conditions of the denitrification assay, dissolved $\mathrm{N}_{2} \mathrm{O}$ would represent approximately $5 \%$ of headspace $\mathrm{N}_{2} \mathrm{O}$ and thus estimates of denitrification reported represent $95 \%$ of actual denitrification rate.

\section{Nitrous Oxide Production in the Soil Profile}

In $1999, \mathrm{~N}_{2} \mathrm{O}$ production at the $0.45-\mathrm{m}$ depth was significantly lower than at the other two soil depths under N120, but did not change with soil depth under $\mathrm{N} 200$, which resulted in a significant $(p=0.043) \mathrm{N} \times$ depth interaction (Table 1). With respect to WTM, $\mathrm{N}_{2} \mathrm{O}$ production was significantly greater under SI than FD in three sampling occasions following $\mathrm{N}$ application (Table 4). Also, $\mathrm{N}_{2} \mathrm{O}$ production did not differ between the 0 - to 0.15 - and the 0.15 - to $0.30-\mathrm{m}$ soil layers, but it was significantly lower in the $0.45-\mathrm{m}$ soil layer than in the two other layers on the 28 July and 26 August sampling dates (Table 4). For $\mathrm{N}_{2} \mathrm{O}$ production in 2000, there were three significant two-factor $(\mathrm{N} \times$ date, WTM $\times$ date and depth $\times$ date) interactions (Tables 1 and 5). The effects of $\mathrm{N}$ application were not significant, except on the 19 September sampling date. Similarly, SI produced greater $\mathrm{N}_{2} \mathrm{O}$ than FD only on the 3 August sampling date. Differences among depths were significant only on 6 July where the 0.15 - to 0.30 -m depth produced the largest amount of $\mathrm{N}_{2} \mathrm{O}$ (Table 5).

Generally speaking, our findings are within the lower range of the values reported by Williams et al. (1992), who compiled and evaluated available data of $\mathrm{N}_{2} \mathrm{O}$ emissions from different agroecosystems and found $\mathrm{N}_{2} \mathrm{O}$ 

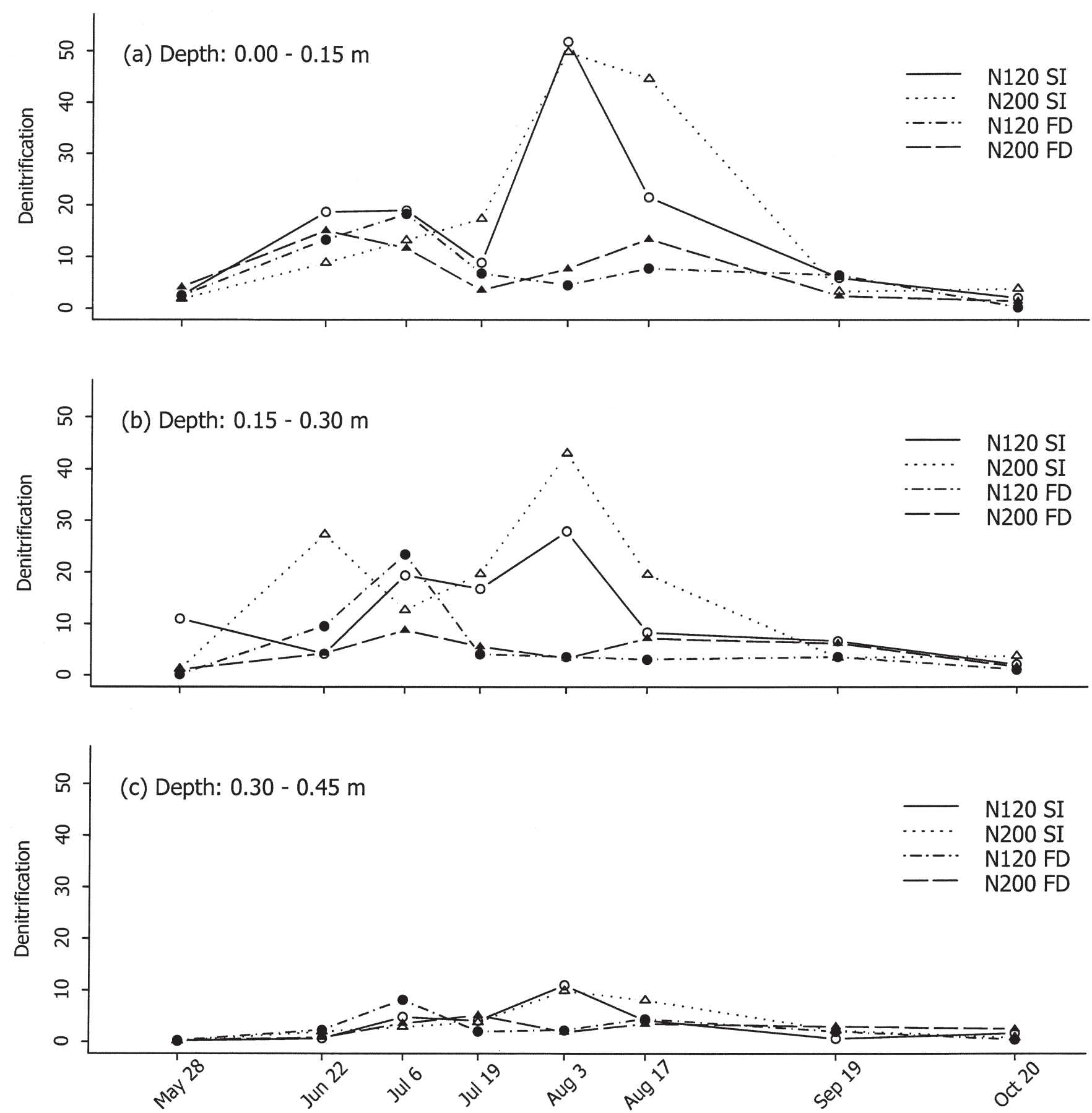

Fig. 1. Interaction effect of fertilizer, water table management (WTM), and date at (a) 0- to 0.15-, (b) 0.15- to 0.30-, and (c) 0.30- to 0.45-m depths on denitrification $\left(\mathrm{g} \mathrm{d}^{-1} \mathrm{ha}^{-1}\right)$ measured in 2000 .

emissions ranging from 2.4 to $136 \mathrm{~g} \mathrm{~d}^{-1} \mathrm{ha}^{-1}$. The amount of $\mathrm{N}$ losses through denitrification obtained in this experiment may be small enough to have little economic or agronomic importance, but significant in terms of their effects on atmospheric chemistry.

\section{Nitrous Oxide to Denitrification Ratio}

The $\mathrm{N}_{2} \mathrm{O}$ to $\left(\mathrm{N}_{2} \mathrm{O}+\mathrm{N}_{2}\right)$ ratios at various sampling dates and depths are presented in Tables 6 and 7. The $\mathrm{N}_{2} \mathrm{O}$ to $\left(\mathrm{N}_{2} \mathrm{O}+\mathrm{N}_{2}\right)$ ratio varied between the two growing seasons and provided an interesting contrast. In 1999, $\mathrm{N}$ rate had no consistent effect on $\mathrm{N}_{2} \mathrm{O}$ to $\left(\mathrm{N}_{2} \mathrm{O}+\mathrm{N}_{2}\right)$ ratio (Table 6). The $\mathrm{N}_{2} \mathrm{O}$ to $\left(\mathrm{N}_{2} \mathrm{O}+\mathrm{N}_{2}\right)$ ratio was greater from N120 treatment than from the N200 treatment in 28 July, and the opposite was observed in 20 October (Table 6). As shown in Table 6, differences among depths within SI were not significant, except for the 18 September sampling, when the largest $\mathrm{N}_{2} \mathrm{O}$ to $\left(\mathrm{N}_{2} \mathrm{O}+\right.$ $\mathrm{N}_{2}$ ) ratio for the season was recorded at the 0.30- to $0.45-\mathrm{m}$ depth. Under FD, the largest fraction of $\mathrm{N}_{2} \mathrm{O}$ was observed under the 0.30 - to $0.45-\mathrm{m}$ depth. 
Table 3. Mean denitrification rate (back-transformed to the original scale) of all treatment combinations of the significant four-factor $(\mathrm{N} \times$ water table management $[$ WTM] $\times$ depth $\times$ date $)$ interaction effect in $2000 . \dagger$

\begin{tabular}{|c|c|c|c|c|c|c|c|c|c|c|}
\hline \multirow[b]{2}{*}{$\mathbf{N}$} & \multirow[b]{2}{*}{ WTM } & \multirow[b]{2}{*}{ Depth } & \multicolumn{8}{|c|}{ Date } \\
\hline & & & 28 May & 22 June & 6 July & 19 July & 3 August & 17 August & 19 September & 20 October \\
\hline \multicolumn{2}{|l|}{ kg $N h^{-1}$} & $\mathbf{m}$ & & & & - g ha & $d^{-1}$ & & & \\
\hline \multirow[t]{3}{*}{120} & SI & 0.15 & B $2.53 \mathrm{ab}$ & AB 18.72 a & AB 18.97 ab & AB 8.87 ab & A 52.07 a & AB 21.53 & AB 5.97 & B 2.02 \\
\hline & & 0.30 & 10.95 a & $4.17 \mathrm{ab}$ & $19.40 \mathrm{ab}$ & $16.80 \mathrm{a}$ & 27.95 ab & 8.36 & 6.68 & 2.13 \\
\hline & & 0.45 & В $0.20 \mathrm{~b}$ & В 0.70 b & A 4.81 ab & A 4.08 ab & A 11.01 ab & A 4.20 & В 0.66 & AB 1.69 \\
\hline \multirow[t]{3}{*}{120} & FD & 0.15 & A $2.45 \mathrm{ab}$ & A 13.34 a & A 18.31 ab & A 6.81 ab & A $4.55 \mathrm{~b}$ & A 7.77 & A 6.48 & B 0.23 \\
\hline & & 0.30 & C $0.20 \mathrm{~b}$ & AB 9.54 ab & A 23.45 a & AB 4.15 ab & AB $3.61 \mathrm{~b}$ & AB 3.11 & AB 3.61 & BC 1.11 \\
\hline & & 0.45 & В $0.30 \mathrm{~b}$ & AB 2.32 ab & A 8.13 ab & AB 2.01 b & AB 2.27 b & AB 4.44 & AB 2.03 & В 0.46 \\
\hline \multirow[t]{3}{*}{200} & SI & 0.15 & B 1.82 ab & AB 8.85 ab & AB $13.20 \mathrm{ab}$ & AB 17.35 a & A 50.00 a & A 44.80 & B 3.29 & B 3.77 \\
\hline & & 0.30 & C 1.22 ab & AB 27.29 a & AB 12.64 ab & AB 19.67 a & A 42.97 a & AB 19.57 & ВC 3.46 & ВC 3.73 \\
\hline & & 0.45 & В 0.19 b & AB 1.95 b & AB $2.87 \mathrm{~b}$ & A 3.78 b & A 9.89 ab & A 8.03 & AB 2.23 & AB 0.82 \\
\hline \multirow[t]{3}{*}{200} & FD & 0.15 & 4.08 ab & 15.06 a & 11.69 ab & $3.57 \mathrm{~b}$ & $7.70 \mathrm{ab}$ & 13.42 & 2.41 & 1.40 \\
\hline & & 0.30 & 1.10 ab & $4.23 \mathrm{ab}$ & 8.71 ab & 5.58 ab & 3.34 b & $\mathbf{7 . 1 7}$ & 6.20 & 1.64 \\
\hline & & 0.45 & В 0.24 b & AB 0.85 b & AB 3.55 ab & A $5.13 \mathrm{ab}$ & AB 1.92 b & AB 3.47 & AB 2.99 & AB 2.51 \\
\hline
\end{tabular}

$\dagger$ Means preceded by the same uppercase letter (within rows) and means followed by the same lowercase letters (within columns) are not significantly different (Tukey-Kramer adjusted $p>0.05)$.

† SI, subirrigation; FD, free drainage.

Table 4. Mean nitrous oxide production rate (back-transformed to the original scale) of all treatment combinations of two significant two-factor (irrigation $\times$ date and depth $\times$ date) interaction effects in $1999 . \dagger$

\begin{tabular}{|c|c|c|c|c|c|c|c|}
\hline \multirow[b]{2}{*}{ WTM } & \multirow[b]{2}{*}{ Depth } & \multicolumn{6}{|c|}{ Date } \\
\hline & & 9 June & 7 July & 28 July & 26 August & 18 September & 20 October \\
\hline & $\mathbf{m}$ & & & & ${ }^{1} \mathbf{d}^{-1}$ & & \\
\hline & & B 1.66 & A 7.26 a & B $1.43 \mathrm{a}$ & B 0.64 a & C 0.13 & C 0.12 \\
\hline \multirow{4}{*}{ FI } & & В 1.55 & A 3.59 b & C 0.38 b & D 0.02 b & D 0.04 & D 0.13 \\
\hline & 0.15 & B 1.47 & A 7.27 & B $1.26 \mathrm{a}$ & B $0.41 \mathrm{a}$ & C 0.05 & C 0.13 \\
\hline & 0.30 & AB 2.56 & A 4.85 & ВC 0.98 a & CD $0.33 \mathrm{a}$ & D 0.08 & D 0.12 \\
\hline & 0.45 & B 1.10 & A 3.78 & C 0.33 b & D 0.01 b & CD 0.10 & CD 0.12 \\
\hline
\end{tabular}

$\dagger$ Means preceded by the same uppercase letter (within rows) and means followed by the same lowercase letters (within columns) are not significantly different (Tukey-Kramer adjusted $p>0.05$ ).

$\uparrow$ SI, subirrigation; FD, free drainage.

Table 5. Mean nitrous oxide production rate (back-transformed to the original scale) of all treatment combinations of the three significant two-factor $(\mathrm{N} \times$ date, water table management [WTM] $\times$ date, and depth $\times$ date $)$ interaction effects in 2000. $\dagger$

\begin{tabular}{|c|c|c|c|c|c|c|c|c|c|c|}
\hline \multirow[b]{2}{*}{$\mathbf{N}$} & \multirow[b]{2}{*}{ WTM } & \multirow[b]{2}{*}{ Depth } & \multicolumn{8}{|c|}{ Date } \\
\hline & & & 28 May & 22 June & 6 July & 19 July & 3 August & 17 August & 19 September & 20 October \\
\hline \multirow{8}{*}{$\begin{array}{l}\text { kg } \mathbf{N} \mathbf{h a}^{-1} \\
120 \\
200\end{array}$} & & m & & & 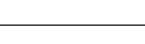 & 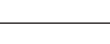 & $h^{-1} d^{-1}$ & & & 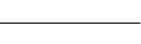 \\
\hline & & & В 0.29 & В 0.46 & A 3.98 & A 2.68 & A 4.13 & A 1.69 & B 0.44 b & В 0.39 \\
\hline & & & D 0.24 & ВC 0.76 & A 4.10 & A 2.21 & A 3.35 & A 2.54 & AB 1.72 a & CD 0.58 \\
\hline & SI & & C 0.26 & C 0.59 & AB 3.51 & A 1.88 & A 7.15 a & B 2.11 & C 0.60 & C 0.44 \\
\hline & FD & & C 0.27 & C 0.59 & A 4.65 & AB 3.15 & AB 1.93 b & AB 2.03 & BC 1.27 & C 0.52 \\
\hline & & 0.15 & BC 0.37 & BC 0.53 & A $2.70 \mathrm{~b}$ & A 2.73 & A 2.93 & AB 1.12 & ВC 0.70 & C 0.26 \\
\hline & & 0.30 & D 0.44 & CD 0.98 & A 7.45 a & BC 1.91 & AB 3.86 & ABC 2.29 & CD 0.82 & D 0.65 \\
\hline & & 0.45 & C 0.11 & ВC 0.39 & A $3.28 \mathrm{ab}$ & A 2.78 & A 4.54 & A 3.47 & AB 1.15 & B 0.65 \\
\hline
\end{tabular}

$\dagger$ Means preceded by the same uppercase letter (within rows) and means followed by the same lowercase letters (within columns) are not significantly different (Tukey-Kramer adjusted $p>0.05)$.

† SI, subirrigation; FD, free drainage.

In 2000, there were two noticeable trends. First, sampling date (time) was significant only under FD and SI receiving $120 \mathrm{~kg} \mathrm{~N} \mathrm{ha}^{-1}$ at the 0.15 - to 0.30 -m sampling depth (Table 7). Second, there were instances when the $\mathrm{N}_{2} \mathrm{O}$ to $\left(\mathrm{N}_{2} \mathrm{O}+\mathrm{N}_{2}\right)$ ratio was greater than 1.0 under FD at the 0.30- to $0.45-\mathrm{m}$ sampling depth (Table 7). These results are in general agreement with those reported by Jacinthe et al. (2000) who observed that concentrations of $\mathrm{N}_{2} \mathrm{O}$ remained high at depths lower than $0.40 \mathrm{~m}$ of soil columns. They attributed this to a low activity of $\mathrm{N}_{2} \mathrm{O}$-reductase at that depth and, consequently, $\mathrm{N}_{2} \mathrm{O}$ was not being reduced at a significant rate.

The average values of $\mathrm{N}_{2} \mathrm{O}$ to $\left(\mathrm{N}_{2} \mathrm{O}+\mathrm{N}_{2}\right)$ ratios were generally higher under FD than under SI during both growing seasons. This was particularly noticeable at the 0.30 - to $0.45-\mathrm{m}$ depth, where the $\mathrm{N}_{2} \mathrm{O}$ to $\left(\mathrm{N}_{2} \mathrm{O}+\mathrm{N}_{2}\right)$ ratios were close or exceeded 1.0 in several sampling dates (Tables 6 and 7). Under some conditions, $\mathrm{N}_{2} \mathrm{O}$ can be produced simultaneously by nitrification and denitrification, so the production of $\mathrm{N}_{2} \mathrm{O}$ from nitrification could affect calculated $\mathrm{N}_{2} \mathrm{O}$ to $\left(\mathrm{N}_{2} \mathrm{O}+\mathrm{N}_{2}\right)$ ratios. If nitrification is a source of $\mathrm{N}_{2} \mathrm{O}$ then the denitrification rate could be underestimated by the $\mathrm{C}_{2} \mathrm{H}_{2}$ inhibition technique (Malone et al., 1998), resulting in $\mathrm{N}_{2} \mathrm{O}$ to $\left(\mathrm{N}_{2} \mathrm{O}+\mathrm{N}_{2}\right)$ ratios of $>1.0$. As indicated earlier, waterfilled pore space was greater under SI than FD. Consequently, denitrification presumably produced the major share of $\mathrm{N}_{2} \mathrm{O}$ and that the major proportion of the gas- 
Table 6. Mean percentage ratio of $\mathrm{N}_{2} \mathrm{O}$ to $\left(\mathrm{N}_{2} \mathrm{O}+\mathrm{N}_{2}\right)$ (back-transformed to the original scale) of all treatment combinations of the significant two-factor $(\mathrm{N} \times$ date) and three-factor (water table management [WTM] $\times$ depth $\times$ date) interaction effects in 1999. $\dagger$

\begin{tabular}{|c|c|c|c|c|c|c|c|c|}
\hline \multirow[b]{2}{*}{ WTM } & \multirow[b]{2}{*}{ Depth } & \multirow[b]{2}{*}{$\mathbf{N}$} & \multicolumn{6}{|c|}{ Date } \\
\hline & & & 9 June & 7 July & 28 July & 26 August & 18 September & 20 October \\
\hline & $\mathbf{m}$ & $\operatorname{kg~N} \mathbf{h a}^{-1}$ & & & & & & \\
\hline SI & 0.15 & & A 0.20 & A 0.21 b & A $0.30 \mathrm{ab}$ & А 0.13 & В 0.01 b & А 0.15 \\
\hline SI & 0.30 & & 0.35 & 0.29 ab & 0.15 b & 0.14 & $0.10 \mathrm{~b}$ & 0.04 \\
\hline SI & 0.45 & & $\mathbf{0 . 3 5}$ & $0.20 \mathrm{~b}$ & 0.23 ab & 0.05 & $0.67 \mathrm{a}$ & 0.12 \\
\hline FD & 0.15 & & AB 0.20 & 0.15 b & $0.72 a$ & 0.5 & AB 0.54 a & В 0.10 \\
\hline FD & 0.30 & & 0.25 & 0.44 ab & 0.52 ab & 0.35 & 0.04 b & 0.3 \\
\hline \multirow[t]{3}{*}{ FD } & 0.45 & & 0.98 & 0.98 a & $0.52 \mathrm{ab}$ & 0.54 & 0.72 a & 0.22 \\
\hline & & 120 & A 0.33 & A 0.34 & A $0.42 \mathrm{a}$ & В 0.09 & В 0.05 & B 0.07 b \\
\hline & & 200 & 0.32 & 0.27 & $0.29 \mathrm{~b}$ & 0.16 & 0.1 & 0.24 a \\
\hline
\end{tabular}

$\dagger$ Means preceded by the same uppercase letter (within rows) and means followed by the same lowercase letters (within columns) are not significantly different (Tukey-Kramer adjusted $p>0.05$ ).

$¥$ SI, subirrigation; FD, free drainage.

eous $\mathrm{N}$ production would have been emitted as $\mathrm{N}_{2}$. The relative contribution of nitrification to $\mathrm{N}_{2} \mathrm{O}$ production may be addressed by differentially inhibiting nitrification and denitrification by varying $\mathrm{C}_{2} \mathrm{H}_{2}$ concentration. An $\mathrm{C}_{2} \mathrm{H}_{2}$ concentration of 5 to $10 \%(\mathrm{v} / \mathrm{v})$ is needed to block $\mathrm{N}_{2} \mathrm{O}$-reductase (Tiedje et al., 1989), but a concentration of $0.01 \%(\mathrm{v} / \mathrm{v})$ is sufficient to block nitrification (Davidson et al., 1986). Field studies of this kind, however, are generally lacking because this approach is prohibitively expensive and can damage the field by removing large-quantity soil core samples. In a study conducted on a different site, Elmi et al. (2003) concluded that the main source of $\mathrm{N}_{2} \mathrm{O}$ is denitrification at water-filled pore space $>60 \%$. We interpret that wet conditions under SI may increase the residence time of $\mathrm{N}_{2} \mathrm{O}$ in the soil by restricting diffusion and, consequently, enhance the reduction of $\mathrm{N}_{2} \mathrm{O}$ to $\mathrm{N}_{2}$. Supporting this argument is the fact that all occasions in which $\mathrm{N}_{2} \mathrm{O}$ to $\left(\mathrm{N}_{2} \mathrm{O}+\mathrm{N}_{2}\right)$ ratio was greater than 1.0 occurred only under FD, possibly because of better aeration encouraging the nitrification process. Under forest soil, Mogge et al. (1998) reported denitrification ratios of $>1.0$ for $50 \%$ of all measurements, suggesting nitrification was much greater importance for $\mathrm{N}_{2} \mathrm{O}$ production than denitrification. Jarvis and Pain (1994) proposed a value of 0.25 (1:4) mole fraction to be used in budget studies to estimate denitrification losses from $\mathrm{N}_{2} \mathrm{O}$ measurements. While this value is favorably comparable with the mole fraction of $\mathrm{N}_{2} \mathrm{O}$ under SI in our study, it will probably underestimate the contribution of $\mathrm{N}_{2} \mathrm{O}$ in agricultural systems where FD is practiced.

These results may have implications when devising strategies to minimize $\mathrm{N}$ pollution from various agricultural practices. According to our findings, a value of 0.40 to 0.45 mole fraction ratio appears to be appropriate for freely drained soils. The values of $\mathrm{N}_{2} \mathrm{O}$ to $\left(\mathrm{N}_{2} \mathrm{O}+\mathrm{N}_{2}\right)$ ratios obtained in our study are greater than those reported by Kliewer and Gilliam (1995) who found the $\mathrm{N}_{2} \mathrm{O}$ fraction represented only a small fraction (2\%) of total denitrification. In their study, water tables were set at a much shallower depth than ours (up to $0.15 \mathrm{~m}$ ), which apparently saturated soil columns and promoted a more complete reduction of $\mathrm{N}_{2} \mathrm{O}$ to $\mathrm{N}_{2}$. For a practical purpose, however, such shallow water tables can only be recommended during the nongrowing period, in order not to interfere with crop growth, tillage, and other field operations.

It is important to point out, however, that the diffusion of the $\mathrm{N}_{2} \mathrm{O}$ generated at a certain depth in the soil profile to the surface soil is a critical factor that determines the final emission at the soil surface. Nitrous oxide produced near the soil surface would probably have readily diffused out of the soil into the atmosphere. In contrast, $\mathrm{N}_{2} \mathrm{O}$ produced at deeper depths may have taken longer to diffuse from the soil, providing more

Table 7. Mean percentage ratio of $\mathrm{N}_{2} \mathrm{O}$ to $\left(\mathrm{N}_{2} \mathrm{O}+\mathrm{N}_{2}\right)$ (back-transformed to the original scale) of all treatment combinations of the significant four-factor $(\mathrm{N} \times$ water table management [WTM] $\times$ depth $\times$ date $)$ interaction effect in 2000. $\dagger$

\begin{tabular}{|c|c|c|c|c|c|c|c|c|c|c|}
\hline \multirow[b]{2}{*}{$\mathbf{N}$} & \multirow[b]{2}{*}{ WTM } & \multirow[b]{2}{*}{ Depth } & \multicolumn{8}{|c|}{ Date } \\
\hline & & & 28 May & 22 June & 6 July & 19 July & 3 August & 17 August & 19 September & 20 October \\
\hline kg $N h^{-1}$ & & m & & & & & & & & \\
\hline 120 & SI & 0.15 & 0.46 & 0.04 & 0.11 b & 0.29 ab & $0.21 \mathrm{ab}$ & 0.12 & 0.06 ab & 0.09 \\
\hline 120 & SI & 0.30 & AB 0.05 & AB 0.27 & A 0.77 ab & AB 0.14 ab & AB 0.24 ab & AB 0.22 & B 0.02 b & AB 0.25 \\
\hline 120 & SI & 0.45 & 0.36 & 0.14 & $0.67 \mathrm{ab}$ & 0.47 ab & $0.61 \mathrm{ab}$ & 0.44 & 0.37 ab & 0.46 \\
\hline 120 & FD & 0.15 & 0.69 & 0.04 & 0.13 b & 0.88 a & 0.29 ab & 0.19 & 0.05 ab & 1.07 \\
\hline 120 & FD & 0.30 & AB 0.30 & B 0.03 & AB $0.22 \mathrm{ab}$ & AB 0.56 ab & A 0.82 ab & AB 0.18 & AB 0.23 ab & АВ 0.69 \\
\hline 120 & FD & 0.45 & 0.53 & 0.36 & 0.39 ab & 1.15 a & $1.13 \mathrm{ab}$ & 0.80 & 0.85 a & 0.7 \\
\hline 200 & SI & 0.15 & 0.10 & 0.09 & $0.28 \mathrm{ab}$ & 0.07 b & 0.12 b & 0.05 & 0.27 ab & 0.15 \\
\hline 200 & SI & 0.30 & 0.24 & 0.05 & $0.21 \mathrm{ab}$ & 0.05 b & 0.13 b & 0.19 & $0.60 \mathrm{ab}$ & 0.11 \\
\hline 200 & SI & 0.45 & 0.59 & 0.16 & $0.65 \mathrm{ab}$ & 0.86 a & 0.85 ab & 0.56 & 0.75 a & 0.52 \\
\hline 200 & FD & 0.15 & 0.07 & 0.09 & $0.24 a b$ & 0.86 a & 0.11 b & 0.05 & 0.84 a & 0.15 \\
\hline 200 & FD & 0.30 & 0.93 & 0.51 & $1.76 \mathrm{a}$ & $0.43 \mathrm{ab}$ & $0.60 \mathrm{ab}$ & 0.27 & 0.27 ab & 0.66 \\
\hline 200 & FD & 0.45 & 0.42 & 0.90 & $1.73 \mathrm{a}$ & 0.81 a & $1.52 \mathrm{a}$ & 1.4 & 0.83 a & 0.66 \\
\hline
\end{tabular}

$\dagger$ Means preceded by the same uppercase letter (within rows) and means followed by the same lowercase letters (within columns) are not significantly different (Tukey-Kramer adjusted $p>0.05$ ).

$\uparrow$ SI, subirrigation; FD, free drainage. 


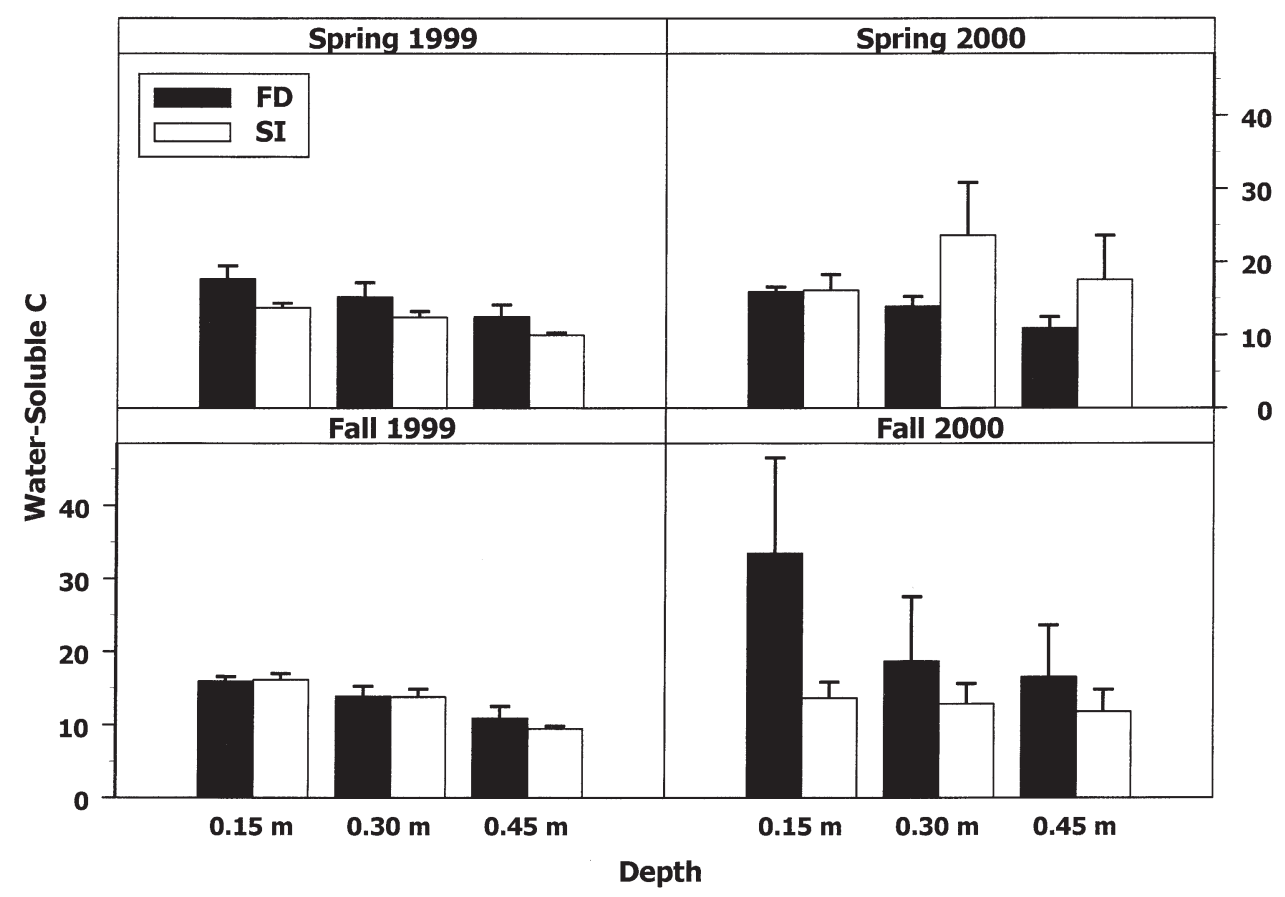

Fig. 2. Water-soluble carbon (WSC) concentration $\left(\mathrm{mg} \mathrm{kg}^{-1}\right)$ in the soil profile in spring and fall of 1999 and 2000 . Vertical bars represent standard error of the mean $(n=6)$.

opportunity for $\mathrm{N}_{2} \mathrm{O}$ to be reduced to $\mathrm{N}_{2}$ rather than being allowed to diffuse into the atmosphere.

\section{Role of Water-Soluble Carbon in Denitrification Activity}

Although both denitrification and $\mathrm{N}_{2} \mathrm{O}$ production decreased with depth in both years, measurable denitrification occurred at depths lower than $0.15 \mathrm{~m}$ (Tables 2-5). McCarty and Bremner (1992) reported very low rates of subsoil (0.25- to 2-m depth) denitrification in response to added $\mathrm{NO}_{3}^{-}-\mathrm{N}$, but addition of both $\mathrm{NO}_{3}^{-}-\mathrm{N}$ and glucose stimulated denitrification activity. They concluded that the low rate of denitrification in subsoils was due to a lack of available organic $\mathrm{C}$.

In our study, however, there were no clear trends with WSC concentrations in the soil profile (Fig. 2). The WSC concentrations remained relatively uniform,

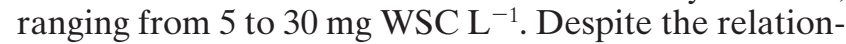
ship between soil organic $\mathrm{C}$ and denitrification that was established decades ago (Burford and Bremner, 1975; Bremner and Shaw, 1958), the critical level of WSC needed for denitrification to proceed is not yet welldefined, particularly in soils with different drainage systems. For example, Beauchamp et al. (1980) observed that regressions of denitrification rate on WSC were nonsignificant with poorly drained soils whereas they were highly significant with well or moderately drained soils. They also noted that a WSC content greater than $40 \mathrm{mg} \mathrm{kg}^{-1}$ soil was required to support denitrifiers. In the Burford and Bremner (1975) study, however, data presented suggest that denitrification can occur at lower WSC levels.

In the present study, concentrations of WSC (Fig. 2) may suggest that WSC in this soil was sufficiently high for denitrification to proceed. Mean WSC concentrations were generally similar or higher in FD than SI (Fig. 2), but the differences were not significant $(p>$ 0.05 ) in all sampling periods. Trends toward lower WSC under SI than FD in spring 1999 and fall 2000 may suggest that WSC in SI plots might have been metabolized at a greater rate than in FD plots.

Water-soluble $\mathrm{C}$ is dynamic and can be influenced by the growth of crops. Although changes in WSC differed little due to sampling period (Fig. 2), we acknowledge that WSC values measured during spring and fall may not reflect accurately the influence of WSC on denitrification dynamics during the growing season. On the basis of the data available, we cannot be definitive how WSC concentrations would have changed within the crop root zone if sampling was continued throughout the growing season. Further study on the dynamic changes of WSC during active plant growth is required to determine whether WSC can explain a significant portion of denitrification process.

\section{CONCLUSIONS}

Denitrification capacity at soil depth has received surprisingly little attention. Information on $\mathrm{N}_{2} \mathrm{O}$ to $\left(\mathrm{N}_{2} \mathrm{O}+\right.$ $\mathrm{N}_{2}$ ) ratio during denitrification is important in assessing the amount of $\mathrm{N}_{2} \mathrm{O}$ production from denitrification and its potential environmental impact. This work reports on a two-year field study during which denitrification, $\mathrm{N}_{2} \mathrm{O}$ production, and their ratio in the subsurface environment $(0-0.45 \mathrm{~m})$ as influenced by WTM and N application rate were quantified. Denitrification rates in the soil profile were generally greater under SI than FD in most sampling dates, irrespective of soil depth and $\mathrm{N}$ rate. We found that ratios of $\mathrm{N}_{2} \mathrm{O}$ to $\left(\mathrm{N}_{2} \mathrm{O}+\mathrm{N}_{2}\right)$ were 
lower in SI plots than FD, suggesting that SI treatment created conditions that enhance further reduction of $\mathrm{N}_{2} \mathrm{O}$. This is an indication that higher denitrification rates under SI than FD do not necessarily add to concerns over global atmospheric $\mathrm{N}_{2} \mathrm{O}$ loadings. Significant amounts of denitrification were measured at deeper soil layers, especially the 0.15 - to 0.30 -m layer. We therefore conclude that the assumption that denitrification in the top soil layer $(0-0.15 \mathrm{~m})$ is representative of the overall rate of denitrification from the soil may not always be true. We recognize that WSC measured before planting and after harvest may not reflect the influence of WSC on denitrification during the growing season. Our results showed no consistent differences between 120 and 200 $\mathrm{kg} \mathrm{N} \mathrm{ha}^{-1}$ rates at any soil depth. Therefore, we conclude that emphasis on $\mathrm{N}$ rate management alone may not be a sufficient strategy to overcome environmental concerns associated with $\mathrm{N}$ applications.

\section{ACKNOWLEDGMENTS}

We thank Mr. Vincent and family for their willingness to contribute to scientific knowledge, and Peter Enright and Peter Kirby whose technical assistance made our field work much easier. We also thank the reviewers for their useful suggestions. This research was supported by a Natural Sciences and Engineering Research Council of Canada (NSERC) grant.

\section{REFERENCES}

Aulakh, M.S., D.A. Rennie, and E.A. Paul. 1984. Gaseous N losses from soil under zero-till compared with conventional-till management systems. J. Environ. Qual. 13:130-136.

Beauchamp, E.G., C. Gale, and J.C. Yeomans. 1980. Organic matter availability for denitrification in soils of different textures and drainage classes. Commun. Soil Sci. Plant Anal. 11:1221-1233.

Bremner, J.M., and K. Shaw. 1958. Denitrification in soil II: Factors affecting denitrification. J. Agric. Sci. 51:40-52.

Burford, J.R., and J.M. Bremner. 1975. Relationships between the denitrification capacities of soils and total, water soluble and readily decomposable soil organic matter. Soil Biol. Biochem. 7:389-394.

Davidson, E.A., W.T. Swank, and T.O. Perry. 1986. Distinguishing between nitrification and denitrification as sources of gaseous nitrogen production in soil. Appl. Environ. Microbiol. 52:1280-1286.

Duxbury, J.M., D.R. Bouldin, R.E. Terry, and R.L. Tate. 1982. Emissions of nitrous oxide from soils. Nature (London) 298:462-464.

Ellis, S., E. Yamulk, R. Dixon, R. Harrison, and S.C. Jarvis. 1998. Denitrification and $\mathrm{N}_{2} \mathrm{O}$ emissions from a UK pasture soil following early spring application of cattle slurry and mineral fertiliser. Plant Soil 202:15-25.

Elmi, A.A., C. Madramootoo, M. Egeh, G. Dodds, and C. Hamel. 2002a. Water table management as a natural bio-remediation technique of nitrate pollution. Water Qual. Res. J. Can. 37:563-576.
Elmi, A.A., C. Madramootoo, M. Egeh, A. Liu, and C. Hamel. 2002b. Environmental and agronomic implications of water table and nitrogen fertilization management. J. Environ. Qual. 31:1858-1867.

Elmi, A.A., C. Madramootoo, C. Hamel, and A. Liu. 2003. Denitrification and nitrous oxide to nitrous oxide plus dinitrogen ratios in the soil profile as influenced by tillage systems and crop residue in a sandy loam soil. Biol. Fertil. Soils 38:340-348.

Elmi, A.A., C. Madramootoo, M. Egeh, and C. Hamel. 2004. Water and fertilizer nitrogen management to minimize nitrate pollution from a cropped soil in southwestern Quebec, Canada. Water Air Soil Pollut. 151:117-134.

Jacinthe, P.A., W.A. Dick, and L.C. Brown. 2000. Bioremediation of nitrate-contaminated shallow soils using water table management techniques: Production and evolution of nitrous oxide. Soil Biol. Biochem. 32:371-382.

Jarvis, S.C., and D.J. Hatch. 1994. Potential for denitrification at depth below long-term grass swards. Soil Biol. Biochem. 26:1629-1636.

Jarvis, S.C., and B.F. Pain. 1994. Greenhouse gas emissions from intensive livestock systems: Their estimation and technologies for reduction. Clim. Change 27:27-38.

Kliewer, B.A., and J.W. Gilliam. 1995. Water management effects on denitrification and nitrous oxide evolution. Soil Sci. Soc. Am. J. 59:1694-1701.

Koops, J.G., O. Oenema, and M.L. Van Beusichem. 1996. Denitrification in the top and sub soil grassland on peat soils. Plant Soil 184: $1-10$.

Littell, R.C., G.A. Milliken, W.W. Stroup, and R.D. Wolfinger. 1996. SAS system for mixed models. SAS Inst., Cary, NC.

MacKenzie, A.F., M.F. Fan, and F. Cardin. 1997. Nitrous oxide emissions as affected by tillage, corn-soybean-alfalfa rotations and nitrogen fertilization. Can. J. Soil Sci. 77:145-152.

Malone, J.P., R.J. Stevens, and R.J. Laughlin. 1998. Combining the $15 \mathrm{~N}$ and acetylene inhibition techniques to examine the effect of acetylene on denitrification. Soil Biol. Biochem. 30:31-37.

McCarty, G.W., and J.M. Bremner. 1992. Availability of organic carbon for denitrification of nitrate in subsoils. Biol. Fertil. Soils 14: 219-222.

Mogge, B., E.-A. Kaiser, and J.-C. Much. 1998. Nitrous oxide emissions and denitrification $\mathrm{N}$-losses from forest soils in the Bonhöved lake region (northern Germany). Soil Biol. Biochem. 30:703-710.

Montgomery, D.C. 2001. Design and analysis of experiments. 5th ed. John Wiley \& Sons, New York.

Ryan, M., D. Noonan, and A. Fanning. 1998. Relative denitrification rates in surface and subsurface layers of mineral soil. Ir. J. Agric. Food Res. 37:141-157.

Ryden, J.C., J.H. Skinner, and D.J. Nixon. 1987. Soil core incubation system for the field measurement of denitrification using acetylene inhibition method. Soil Biol. Biochem. 19:753-757.

SAS Institute. 1999. SAS online doc. Version 8. SAS Inst., Cary, NC.

Tiedje, J.M., S. Simkins, and P.M. Groffman. 1989. Perspectives on measurement of denitrification in the field including recommended protocols for acetylene based methods. Plant Soil 115:261-284.

Velthof, G.C., A.B. Brader, and O. Oenema. 1996. Seasonal variations in nitrous oxide losses from managed grasslands in the Netherlands. Plant Soil 181:263-274.

Williams, E.J., G.L. Hutchinson, and F.C. Fehsenfeld. 1992. $\mathrm{NO}_{\mathrm{x}}$ and $\mathrm{N}_{2} \mathrm{O}$ emissions from soil. Global Biogeochem. Cycles 6:351-388. 